Jurnal Penelitian Karet, 2018, 36 (2) : 109 - 116

Indonesian J. Nat. Rubb. Res. 2018, 36 (2) : 109 - 116

Doi : https://doi.org/10.22302/ppk.jpk.v36i2.558

\title{
BEBERAPA SISTEM SADAP ALTERNATIF PADA KLON BPM 24
}

\author{
Some of the Alternative Tapping Systems on BPM 24 Clone
}

Eva HERLINAWATI*, Martini AJI dan KUSWANHADI

Balai Penelitian Sembawa, Pusat Penelitian Karet

Jalan Palembang-Pangkalan Balai Km 29 PO BOX 1127 Palembang 30001

*Email : eva_herlinawati@yahoo.com

Diterima : 3 September 2018 / Disetujui : 7 November 2018

\begin{abstract}
When tapping was not conducted properly, it will caused damage of renewal bark and low yield. Several alternative of tapping systems need to be studied such as stimulation, double cut, and small cut. The purpose of this study was to know the effect of alternative of tapping system on physiological condition, growth, and yield of BPM 24. The experiment was carried out at Sembawa Research Center and used BPM 24 clone. The experiment was arranged in randomized completely block design with six treatments and four replications. The result showed that double cut (S/4 U d3 ET2.5\% Ga1 9/y (m) + $\mathrm{S} / 2$ d3 dan $\mathrm{S} / 4 \mathrm{U}$ d3 ET 2.5\% Ga1 9/y (m) + $\mathrm{S} / 4$ d3 ET2.5\% 9/y $(\mathrm{m})$ ) did not increase yield compare to conventional system (S/2 d3). The combination between small cut and stimulation decreased yield. Double cut declined dry rubber content and increment of girth.
\end{abstract}

Keywords : double cut, S/2, small cut, yield, dry rubber content, firth, sucrose, inorganic phosphorus, thiol, stimulation, latex, Hevea, tapping system.

\footnotetext{
Abstrak

Penyadapan yang tidak benar akan menghasilkan kulit pulihan yang buruk dan rendah produksinya. Beberapa alternatif sistem sadap perlu diteliti antara lain aplikasi stimulan, sistem sadap ganda, dan irisan sadap pendek. Tujuan penelitian ini adalah untuk mengetahui pengaruh beberapa alternatif sistem sadap terhadap karakter fisiologi, pertumbuhan, dan produksi klon BPM 24. Penelitian
}

dilaksanakan di Kebun Percobaan Balai Penelitian Sembawa, menggunakan klon BPM 24, dan rancangan acak kelompok dengan 6 perlakuan dan 4 ulangan. Hasil penelitian menunjukkan bahwa irisan ganda (S/4 U d3 ET2.5\% Ga1 9/y (m) + S/2 d3 dan S/4 U d3 ET 2.5\% Ga1 9/y (m) + S/4 d3 ET2.5\% 9/y (m)) tidak mampu meningkatkan produksi dibanding sistem konvensional (S/2 d3). Kombinasi antara irisan pendek dan stimulasi justru menurunkan produksi karet kering. Irisan ganda menurunkan kadar karet kering (KKK) dan pertumbuhan lilit batang.

Kata kunci : Irisan ganda, $\mathrm{S} / 2$, irisan pendek, produksi, KKK, lilit batang, sukrosa, fosfat anorganik, tiol, stimulan, lateks, Hevea, sistem sadap.

\section{PENDAHULUAN}

Batang tanaman karet tersusun atas kulit keras dan kulit lembut. Di dalam kulit keras terdapat pembuluh lateks, yang berfungsi untuk membentuk dan menyimpan lateks. Pada kondisi pertumbuhan yang normal dan proses penyadapan yang baik, jumlah pembuluh lateks pada kulit pulihan lebih banyak dibandingkan kulit perawan (Riches \& Gooding, 1952; Webster \& Paardekooper, 1989). Namun proses penyadapan yang tidak benar pada kulit perawan menyebabkan dampak yang fatal terhadap pertumbuhan kulit pulihan. Kondisi kulit pulihan yang kurang optimal akan menyebabkan menurunnya jumlah pembuluh lateks dan berlanjut pada penurunan produksi lateks. 
Kulit pulihan yang buruk membutuhkan beberapa alternatif sistem sadap. Tujuan adanya alternatif sistem sadap adalah untuk mengoptimalkan produktivitas. Alternatif pertama yang dapat diterapkan adalah aplikasi stimulasi. stimulan dapat meningkatkan produksi lateks dengan memperlama aliran lateks dan mengaktifkan metabolisme sel lateks (Tungngoen et al., 2009; d'Auzac \& Jacob, 1984; Gohet et al., 2008; Silpi et al., 2006; Jacob et al.,1989). Alternatif kedua adalah dengan menerapkan sistem sadap irisan ganda. Penyadapan dengan sistem sadap irisan ganda dilakukan pada panel B1-1 dan HO-1 selama 4 tahun. Penerapan sistem sadap ganda diharapkan dapat menggali potensi produksi pada kulit pulihan dan panel atas pada klon metabolisme mediumrendah. Dengan penerapan irisan ganda produksi rata-rata dapat meningkat 50-90\% dan aman terhadap kejadian kering alur sadap (KAS) dibandingkan dengan sistem sadap konvensional (Sumarmadji et al., 2005; Pulungan et al., 2009).

Sedangkan alternatif ketiga adalah dengan mengurangi panjang alur sadap yang dikombinasikan dengan stimulasi. Panjang alur sadap memiliki pengaruh yang besar terhadap pola aliran lateks. Pada panjang alur sadap yang pendek akan terjadi indeks penyumbatan yang besar, tekanan turgor tinggi, dan produksi per pembuluh lateks yang lebih tinggi (Southern \& Gomez, 1970). Kondisi tersebut mengindikasikan bahwa terjadi hambatan aliran lateks sehingga perlu dikombinasikan dengan stimulasi (Langlois, 1969).

Penelitian ini bertujuan untuk mengetahui beberapa alternatif sistem sadap dengan stimulasi terhadap karakter fisiologi, pertumbuhan, dan produksi klon BPM 24. Alternatif sistem sadap yang tepat adalah sistem sadap yang mempunyai produksi tertinggi tanpa menimbulkan efek negatif terhadap metabolisme dalam sel lateks.

\section{BAHAN DAN METODE}

Penelitian dilaksanakan di Kebun Percobaan Balai Penelitian Sembawa mulai Januari 2013 sampai Agustus 2015. Percobaan disusun berdasarkan Rancangan Acak Kelompok dengan 6 perlakuan dan 4 ulangan. Percobaan menggunakan klon BPM 24 tahun tanam 1997 yang ditanam dengan jarak tanam $6 \mathrm{~m}$ x $3 \mathrm{~m}$. Klon BPM 24 tergolong klon responsif stimulan. Kondisi kulit pulihan pada penelitian ini tergolong bagus dan potensial. Perlakuan untuk masing-masing klon dapat dilihat pada Tabel 1 .

Pengamatan dilakukan terhadap peubah produksi, kadar karet kering lateks, kadar sukrosa, kadar fosfat anorganik, kadar tiol, dan intensitas kering alur sadap. Pengamatan produksi dilakukan setiap hari sadap, sedangkan kering alur sadap setiap 6 bulan. Pengambilan sampel lateks untuk analisis lateks dilakukan Maret-Mei.

Produksi karet ditimbang sebagai lateks dan lump mangkok. Kadar karet kering (KKK) lateks diukur dengan menggunakan pendekatan metode panci penggorengan, pengeringan lateks dilakukan dengan oven suhu $100^{\circ} \mathrm{C}$ hingga bobotnya tetap (Solichin et al., 2012).

Kadar sukrosa, fosfat anorganik, dan tiol diukur di laboratorium dengan menggunakan spektrofotometer, masingmasing absorbansi diukur pada panjang gelombang 620, 740, dan 412 nm. Setiap sampel lateks $(1 \mathrm{ml})$ diambil dan dipreparasi ke dalam $9 \mathrm{ml}$ TCA 2,5\% (asam trikloro asetat) menjadi serum TCA. Pengukuran kadar sukrosa lateks menggunakan metode Anthrone (Dische, 1962). Kadar fosfat anorganik berdasarkan pengikatan oleh ammonium molibdat yang kemudian tereduksi oleh $\mathrm{FeSO}_{4}$ dalam reaksi asam (Taussky \& Shorr, 1953). Kadar tiol diukur berdasarkan prinsip reaksinya dengan asam dithiobisnitrobenzoat (DTNB) yang membentuk TNB yang berwarna kuning (McMullen, 1960). 
Tabel 1. Rincian perlakuan sistem sadap Table 1. Summary of tapping system treatment

\begin{tabular}{|c|c|c|}
\hline $\begin{array}{l}\text { Perlakuan } \\
\text { Treatment }\end{array}$ & $\begin{array}{l}\text { Sistem sadap } \\
\text { Tapping System }\end{array}$ & $\begin{array}{c}\text { Keterangan } \\
\text { Remarks }\end{array}$ \\
\hline 1 & $\begin{array}{l}\mathrm{S} / 2 \text { d3 ET2.5\% } \\
\text { Ga1 } 18 / \mathrm{y}(2 \mathrm{w}) \\
\text { (kontrol) }\end{array}$ & $\begin{array}{l}\text { Penyadapan setengah spiral } 3 \text { hari sekali dengan stimulan } \\
\text { etefon } 2.5 \% \text { aplikasi pada groove sebanyak } 1 \text { gram/pohon } \\
\text { dengan interval } 2 \text { minggu sekali, aplikasi } 18 \mathrm{kali} / \text { tahun (B1- } \\
\text { 1), musim gugur daun selama } 3 \text { bulan tanpa stimulan. }\end{array}$ \\
\hline 2 & $\begin{array}{l}\mathrm{S} / 2 \text { d3 ET2.5\% } \\
\text { Ga1 36/y (w) }\end{array}$ & $\begin{array}{l}\text { Penyadapan setengah spiral } 3 \text { hari sekali dengan stimulan } \\
\text { etefon } 2.5 \% \text { aplikasi pada groove sebanyak } 1 \text { gram/pohon } \\
\text { dengan interval seminggu sekali, aplikasi } 36 \mathrm{kali} / \text { tahụ (B1- } \\
\text { 1), musim gugur daun selama } 3 \text { bulan tanpa stimulan }\end{array}$ \\
\hline 3 & $\begin{array}{l}\mathrm{S} / 4 \mathrm{U} \mathrm{d} 3 \mathrm{ET} 2.5 \% \\
\text { Ga1 9/y (m) }+\mathrm{S} / 2 \\
\mathrm{~d} 3\end{array}$ & $\begin{array}{l}\text { Penyadapan seperempat spiral ke atas } 3 \text { hari sekali dengan } \\
\text { stimulan etefon } 2.5 \% \text { aplikasi pada groove sebanyak } 1 \\
\text { gram/pohon dengan interval sebulan sekali, aplikasi } 9 \\
\text { kali/tahun (H0-1) dan penyadapan setengah spiral ke bawah } \\
3 \text { hari sekali (B1-1), musim gugur daun selama } 3 \text { bulan } \\
\text { tanpa stimulan. }\end{array}$ \\
\hline 4 & $\begin{array}{l}\mathrm{S} / 4 \mathrm{Ud} \text { d ET } 2.5 \% \\
\mathrm{Ga} 19 / \mathrm{y}(\mathrm{m})+\mathrm{S} / 4 \\
\mathrm{~d} 3 \mathrm{ET} 2.5 \% 9 / \mathrm{y}(\mathrm{m})\end{array}$ & $\begin{array}{l}\text { Penyadapan seperempat spiral ke atas } 3 \text { hari sekali dengan } \\
\text { stimulan etefon } 2.5 \% \text { aplikasi pada groove sebanyak } 1 \\
\text { gram/pohon dengan interval sebulan sekali, aplikasi } 9 \\
\text { kali/tahun (H0-1) dan penyadapan seperempat spiral } \\
\text { ke bawah } 3 \text { hari sekali dengan stimulan etefon } 2.5 \% \text { aplikasi } \\
\text { pada groove sebanyak } 1 \text { gram/pohon dengan interval } \\
\text { sebulan sekali, aplikasi } 9 \text { kali/tahun (B1-1), musim gugur } \\
\text { daun selama } 3 \text { bulan tanpa stimulan. }\end{array}$ \\
\hline 5 & $\begin{array}{l}\mathrm{S} / 4 \mathrm{U} \text { d3 ET } 10 \% \\
\text { Ba1 9/y (m) }\end{array}$ & $\begin{array}{l}\text { Penyadapan seperempat spiral ke atas } 3 \text { hari sekali dengan } \\
\text { stimulan etefon } 10 \% \text { aplikasi pada kulit sebanyak } 1 \\
\text { gram/pohon dengan interval sebulan sekali, aplikasi } 9 \\
\text { kali/tahụn (H0-1), musim gugur daun selama } 3 \text { bulan tanpa } \\
\text { stimulan }\end{array}$ \\
\hline 6 & $\begin{array}{l}\text { S/8 U d3 ET20\% } \\
\text { Ba1 4/y }\end{array}$ & $\begin{array}{l}\text { Penyadapan seperdelapan spiral ke atas } 3 \text { hari sekali dengan } \\
\text { stimulan etefon } 20 \% \text { aplikasi pada kulit sebanyak } 1 \\
\text { gram/pohon, aplikasi } 4 \text { kali/tahun (HO-1), pada saat daun } \\
\text { terbaik bulan April, Mei, Juni, dan Juli. }\end{array}$ \\
\hline
\end{tabular}

Persentase kering alur sadap (KAS) dilakukan secara visual dan diubah dengan penilaian persentase yaitu tidak ada KAS (0\%), $1-25 \%$ alur sadap kering, 26-50\% alur sadap kering, $51-75 \%$ alur sadap kering, dan $76-100 \%$ alur sadap kering.

Data dianalisis dengan menggunakan software Statistical Analysis System (SAS) dan dilanjutkan dengan menggunakan Uji jarak berganda Duncan pada taraf kepercayaan $5 \%$.

\section{HASIL DAN PEMBAHASAN}

Produksi karet kering antara perlakuan 2, 3, dan 4 (irisan ganda) dibandingkan dengan kontrol (konvensional) ternyata tidak memberikan pengaruh nyata (Tabel 1). Irisan ganda khususnya pada perlakuan 3 dan 4 juga tidak mampu meningkatkan produksi. Kombinasi antara irisan pendek dan stimulasi (perlakuan 5 dan 6) justru menurunkan produksi karet kering dibandingkan dengan kontrol. Namun demikian penyadapan dengan irisan pendek (perlakuan 6) mempunyai KKK yang lebih besar dibandingkan dengan irisan setengah spiral. Kadar karet kering (KKK) menurun dengan meningkatnya panjang alur sadap. Hal ini menunjukkan bahwa terjadi hambatan aliran (Abraham et al., 1969).

Berdasarkan variasi musiman terlihat bahwa antara kontrol dengan perlakuan penambahan frekuensi stimulasi dan irisan 
ganda (perlakuan 2, 3, dan 4) mempunyai pola produksi yang relatif sama pada tiap bulan (Gambar 1). Sedangkan irisan pendek (perlakuan 6) mempunyai pola produksi yang rendah pada ketiga tahun pengamatan. Dengan memperhatikan hal tersebut, maka sebaiknya irisan ganda diterapkan dengan melihat kondisi fisiologis awal tanaman. Kondisi awal sebelum penelitian menggambarkan bahwa klon tersebut telah mempunyai aktivitas metabolisme tinggi. Sedangkan pola produksi pada semua perlakuan mengalami penurunan di tiap tahunnya, hal ini disebabkan adanya perbedaan curah hujan yang drastis antara tahun 2013-2015. Tahun 2014 dan 2015 (1851,4 $\mathrm{mm} / \mathrm{tahun}$ dan 1444,54 $\mathrm{mm}$ / tahun) memiliki curah hujan yang lebih rendah dibandingkan dengan tahun 2015 (3451 mm/tahun).
Perbedaan sistem sadap pada klon BPM 24 tidak memberikan perbedaan yang nyata terhadap parameter kadar sukrosa, fosfat anorganik, dan tiol. Hal ini menggambarkan bahwa hasil asimilat dapat secara efektif menjadi lateks melalui perlakuan eksploitasi. Kadar sukrosa lateks telah mencapai kadar terendah yaitu berkisar 1,69-2,35 mM. Sedangkan kadar fosfat anorganik juga tidak mengalami perbedaan dengan penambahan frekuensi stimulasi dari 18/y menjadi 36/y. Irisan ganda juga tidak memberikan pengaruh yang nyata terhadap kadar fosfat anorganik. Kondisi tersebut menandakan bahwa aktivitas metabolisme tanaman telah mencapai batas maksimum yang ditandai dengan tingginya kadar fosfat anorganik dan rendahnya kadar sukrosa lateks. Ditinjau dari kadar tiol, perubahan sistem sadap tidak memberikan perbedaan yang

Tabel 2. Produksi dan parameter fisiologi pada berbagai perlakuan Table 2. Production and physiology parameters at various treatment

\begin{tabular}{|c|c|c|c|c|c|c|c|c|}
\hline \multirow{2}{*}{$\begin{array}{l}\text { Perlakuan } \\
\text { Treatment }\end{array}$} & \multirow{2}{*}{$\begin{array}{c}\text { Sukrosa } \\
\text { Sucrose } \\
(\mathrm{mM})\end{array}$} & \multirow{2}{*}{$\begin{array}{c}\mathrm{Pi} \\
P i \\
(\mathrm{mM})\end{array}$} & \multirow{2}{*}{$\begin{array}{l}\text { Tiol } \\
\text { Thiol } \\
(\mathrm{mM})\end{array}$} & \multicolumn{2}{|c|}{$\begin{array}{l}\text { KAS } \\
T P D \\
(\%)\end{array}$} & \multirow{2}{*}{$\begin{array}{c}\text { Pertambahan } \\
\text { lilit batang } \\
\text { Grith } \\
\text { (cm) }\end{array}$} & \multirow[t]{2}{*}{$\begin{array}{c}\mathrm{KKK} \\
D R C \\
(\%)\end{array}$} & \multirow[t]{2}{*}{$\begin{array}{c}\text { Produksi } \\
\text { Production } \\
\text { (kg/Ha/tahun) }\end{array}$} \\
\hline & & & & B1-1 & HO- 1 & & & \\
\hline $\begin{array}{l}\text { S/2 d3 ET2.5\% Ga1 } \\
18 / y(2 \mathrm{w})\end{array}$ & $1.92 \mathrm{tn}$ & $20.19 \mathrm{tn}$ & $0.54 \mathrm{tn}$ & 17.75 & - & $3.15 \mathrm{~b}$ & $33.96 \mathrm{bc}$ & $2457.32 \mathrm{a}$ \\
\hline $\begin{array}{l}\mathrm{S} / 2 \text { d3 ET2.5\% Ga1 } \\
36 / \mathrm{y}(\mathrm{w})\end{array}$ & 1.69 & 23.81 & 0.52 & 26.5 & - & $2.55 \mathrm{bc}$ & $33.91 \mathrm{bc}$ & $2474.55 \mathrm{a}$ \\
\hline $\begin{array}{l}\mathrm{S} / 4 \mathrm{U} \text { d3 ET2.5\% } \\
\text { Ga1 9/y (m) + S/2 } \\
\text { d3 }\end{array}$ & 2.35 & 25.93 & 0.55 & 18.25 & 11.5 & $2.29 \mathrm{c}$ & $33.73 \mathrm{c}$ & $2566.60 \mathrm{a}$ \\
\hline $\begin{array}{l}\mathrm{S} / 4 \mathrm{U} \text { d3 ET } 2.5 \% \\
\mathrm{Ga} 19 / \mathrm{y}(\mathrm{m})+\mathrm{S} / 4 \\
\text { d3 ET2.5\% 9/y (m) }\end{array}$ & 1.92 & 24.32 & 0.47 & 5 & 5 & $2.49 \mathrm{bc}$ & $34.14 \mathrm{~b}$ & $2514.96 \mathrm{a}$ \\
\hline $\begin{array}{l}\text { S/4 U d3 ET 10\% } \\
\text { Ba1 9/y (m) }\end{array}$ & 2.35 & 25.00 & 0.41 & - & 0 & $2.13 \mathrm{c}$ & $34.21 \mathrm{~b}$ & $2167.69 \mathrm{~b}$ \\
\hline $\begin{array}{l}\text { S/8 U d3 ET20\% } \\
\text { Ba1 4/y }\end{array}$ & 1.92 & 19.79 & 0.44 & - & 0.25 & $4.25 \mathrm{a}$ & $38.20 \mathrm{a}$ & $1515.88 \mathrm{c}$ \\
\hline & tn & tn & tn & & & * & * & * \\
\hline
\end{tabular}

Keterangan : Angka yang diikuti huruf sama pada kolom sama menunjukkan tidak beda nyata pada taraf signifikasi 5 $\%$ (values followed by the same letter in the same column, are not significantly different at 5\%)

** Jumlah pohon/Ha efektif yang disadap 350 pohon dan 100 hari sadap efektif per tahun (the number of trees/Ha effectively tapped 350 trees and 100 tapping days effective peryear) 

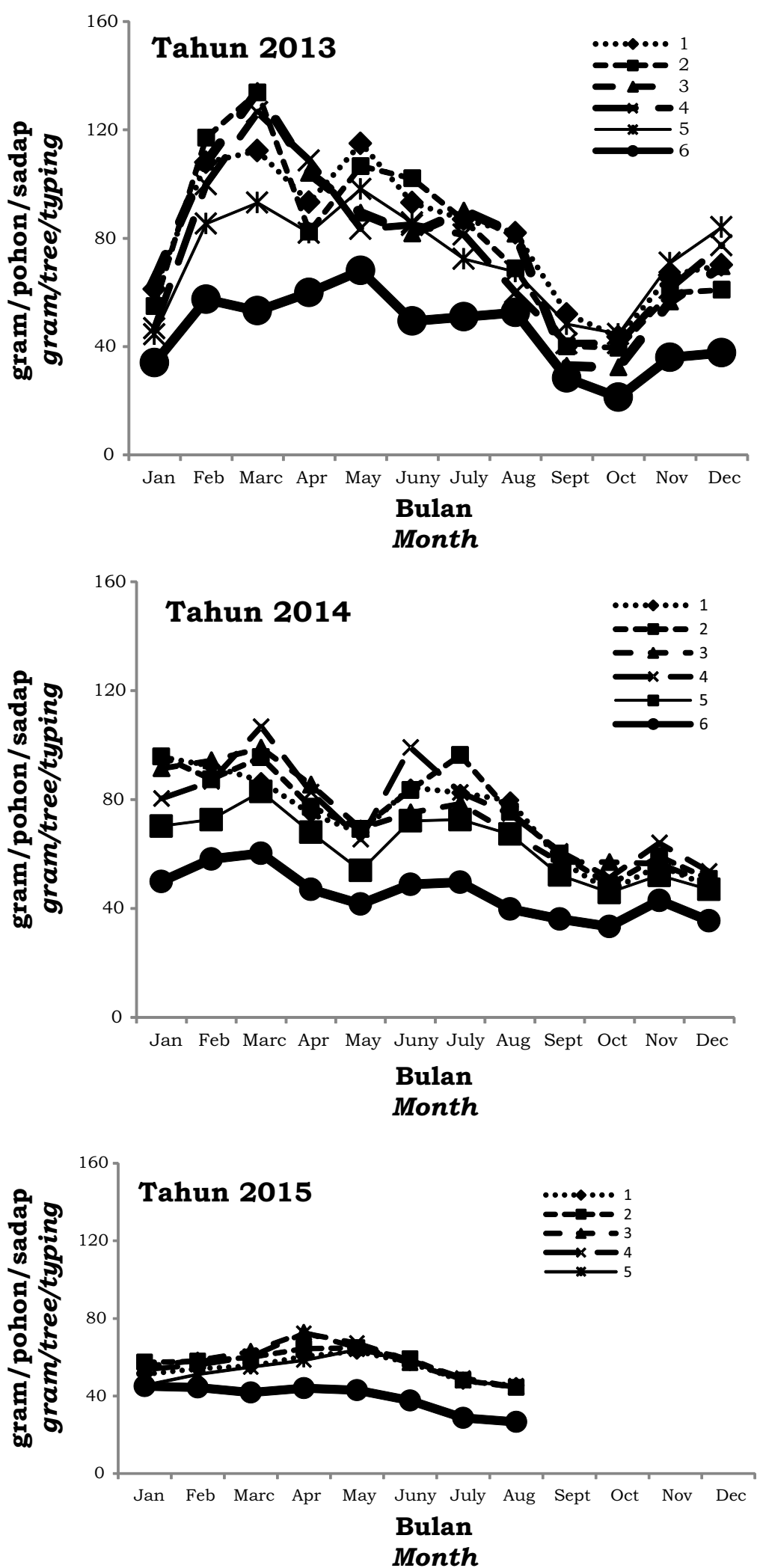

Gambar 1. Pola produksi klon BPM 24 dengan berbagai perlakuan sistem sadap Figure 1. Clone BPM 24 production pattern at various tapping system treatment 

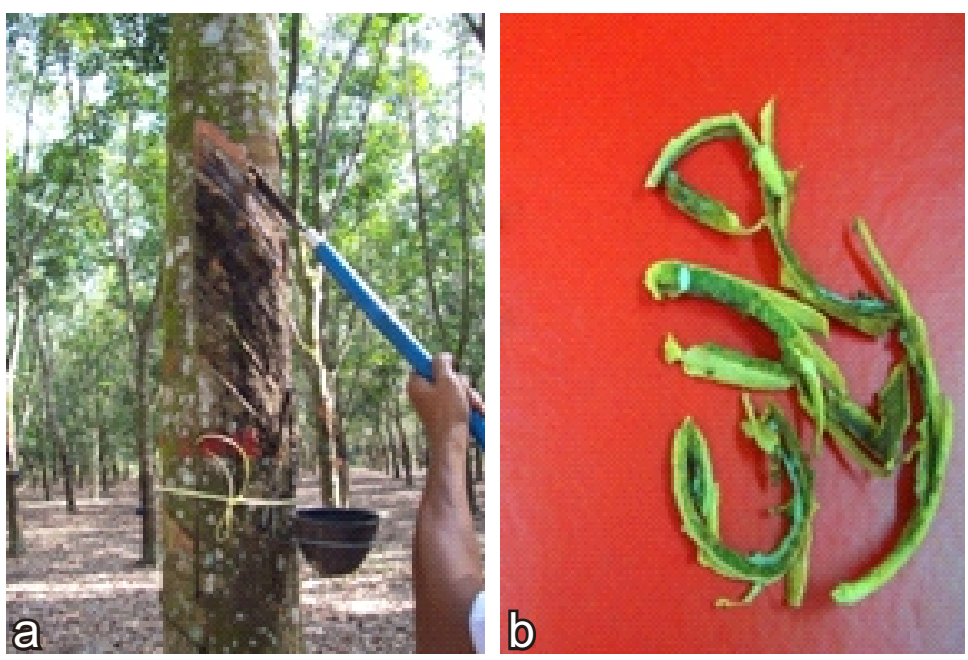

Gambar 2. Penyadapan panel atas. a) proses penyadapan pada panel atas; b) konsumsi kulit pada panel atas.

Figure 2. Tapping at upper. a) Tapping process at upper panel b) Bark consumption at upper panel

signifikan dan secara umum kondisi tanaman masih tergolong baik yaitu tanaman belum mengalami keletihan fisiolog.

Penerapan sistem sadap selain ditinjau dari aspek fisiologi dan produksi tanaman, juga dapat dikaitkan dengan kesehatan dan pertumbuhan tanaman. Peningkatan frekuensi stimulasi (antara perlakuan 1 dan 2) meningkatkan persentase KAS. Sedangkan persentase KAS pada irisan ganda pada panel bawah mempunyai persentase yang relatif sama dengan penyadapan setengah spiral. Sedangkan panel atas pada irisan ganda mempunyai persentase KAS yang cukup rendah namun perlu diantisipasi. Panjang alur sadap yang pendek mempunyai persentase KAS yang lebih rendah dibandingkan dengan alur sadap setengah spiral. Sedangkan pertambahan lilit batang menunjukkan perbedaan nyata. Irisan ganda pada perlakuan 3 menurunkan pertumbuhan lilit batang. Sebaliknya, irisan pendek mempunyai lilit batang yang paling tinggi dibandingkan dengan perlakuan yang lain.

Walaupun dengan sistem sadap irisan pendek ke arah atas diharapkan dapat menghemat konsumsi kulit, namun kendala yang perlu dipertimbangkan adalah mutu sadapan yang biasanya kurang baik (Gambar 2a). Pada umumnya konsumsi kulit lebih tebal dua kali lipat dibandingkan dengan $\mathrm{S} / 2$, karena penyadap lebih sulit untuk mengontrol sadapan (Gambar 2b). Berdasarkan produksi karet kering dan pertimbangan aspek fisiologi, irisan sadap ganda mungkin lebih baik dapat diterapkan dengan mengatur jarak antara panel bawah dengan atas atau mungkin lebih baik dengan melakukan modifikasi dengan "double cut alternative" (DCA). Posisi panel sadap pada DCA adalah berlawanan yakni jika penyadapan dilakukan di panel B1-1 maka panel atas dilakukan di HO-2. Hal ini agar mengurangi kompetisi terhadap karbohidrat, air dan unsur hara (Chantuma et al., 2015). Pertimbangan demikian perlu dikonfirmasi dengan pertimbangan teknis, yang selama ini dianggap lebih mudah dan praktis jika panel bawah dan atas sebidang.

\section{KESIMPULAN}

Pada kondisi kulit pulihan yang tergolong baik, irisan ganda $(\mathrm{S} / 4 \mathrm{U}$ d3 ET2.5\% Ga1 9/y (m) + S/2 d3 dan S/4 U d3 ET 2.5\% Ga1 9/y (m) + S/4 d3 ET2.5\% 9/y (m)) tidak mampu meningkatkan produksi dibanding sistem konvensional $(\mathrm{S} / 2$ d3 
ET2.5\% Ga1 18/y (2w)). Irisan ganda menurunkan kadar karet kering (KKK) dan pertumbuhan lilit batang. Sedangkan kombinasi antara irisan pendek dan stimulasi menurunkan produksi karet kering dan kualitas sadap yang kurang baik.

\section{DAFTAR PUSTAKA}

Chantuma, P., Lacointe, A., Kasemsap, P., Thanisawanyangkura, S., Gohet, E., Clement, A., Guilliot, A., Ameglio, T., \& Thaler, P. (2009). Carbohydrate storage in wood and bark of rubber trees submitted to different level of $\mathrm{C}$ demand induced by latex tapping. Tree Physiology, 29(8), 1021-1031. doi: 10.1093/treephys/tpp043.

d'Auzac, J., \& Jacob, J.L. (1984). Physiology of the laticiferous system in hevea basis and application to productivity. Compte-Rendu du Colloque : Exploitation and Physiology Amelioration. Proceedings of the IRRDB, p. 69-73. Perancis: CIRAD.

Dische, Z. M. (1962). Carbohydrate Chem. Acad. Press. $1: 488$

Gohet, E., Scomparin, C., Cavaloc, E., Balerin, Y., Benites, G., Dumortier, F., Williams, H., Permadi, H.P., Ginting, E., de Rostolan, E., Uche, E., Chegbene, P., Hocepied, E., Echimane, P., Soumahoro, M., Sargeant, H.J., Suyatno, Najera, C.A., Soumahoro, B., Lacote, R., \& Eschbach, J.M. (2008). Influence of ethephon stimulation on latex physiological parameter and conquences on latex diagnosis implementation in rubber agroindustry. IRRDB Workshop : Latex Harvesting Technology. Selangor, Malaysia: MRB \& IRRDB.

Jacob, J.L., Prevot, J.C., Roussel, D., Lacrotte, R., Serres, E., d'Auzac, J., Eschbach, J.M., \& Omont, H. (1989). Field limiting factors, latex physiological parameters, latex diagnosis, and clonal typology. In Physiology of Rubber Tree Latex: the laticiferous cell and latex, a model of cytooplasm. Boca Raton, USA: CRC Press
Kok, N.E., Abraham, P.D., Chin, P.T., \& Kang, L.C. (1969): Exploitation of modern Hevea clones. J.Rubber Res. Inst. Malaya, 21(3), 292 - 329.

Langlois, S. (1969). Influence of lenght and position of tapping cut and direction and frequency of tapping on yield of clone PR 107. Proceed. Nat. Rub. Conf. 1968. Part I. (K.L.) et R.R.I.M. 21: 330340.

McMullen, A.I. (1960). Thiol of low moleculer weight in Hevea brasiliensis latex. Biochem. Biophys. Acta., 41, 152-154.

Pulungan, A.M., Sundiandi, Sudaryanto, S., \& Karyudi. (2009). Penerapan sistem eksploitasi karet untuk peningkatan produktivitas dan kinerja bisnis karet di PT. Perkebunan Nusantara III (Persero). Pertemuan Teknis Eksploitasi Tanaman Karet 2009. Medan, Indonesia : Pusat Penelitian Karet.

Riches, I. P., \& Gooding, E.G.B. (1952). Studies In The Physiology Of Latex : Latex Flow On Tapping-Theoretical Considerations. New Phytol. 51(1), 110

Silpi, U., Thaler, P., Kasemsap, P., Lacointe, A., Chantuma, A., Adam, B., Gohet, E., Thaniswanyankura, S., \& Ameglio, T. (2006). Effect of tapping activity on the dinamics of radial growth of Hevea brasiliensis trees. Tree Physiology, 26(12), 1579-1587.

Solichin, M., Suwardin, D., \& Vachlepi, A. (2012). Saptabina Usahatani Karet Rakyat : Pengolahan. Palembang, Indonesia : Balai Penelitian SembawaPusat Penelitian Karet.

Sumarmadji, Karyudi, Siregar, T.H.S., \& Junaidi, U. (2005). Optimasi produksi klon karet melalui berbagai sistem eksploitasi. Prosiding Lokakarya Nasional Pemuliaan Tanaman Karet 2005. Medan, Indonesia : Pusat Penelitian Karet. 
Southern, W.A., \& Gomez, J.B. (1970). Latex flow studies VII. Influence of length of tapping cut on latex flow pattern. Journal of the Rubber Research Institute Of Malaya., 23(1), 15-22.

Taussky, H.H., \& Shorr, E. (1953). A micro colorimetric methods for the determination of inorganic phosphorus. J. Biol. Chem., 202, 675685.

Tungngoen, K., Kongsawadworakul, P., Viboonjun, U., Katsuhara, M., Brunel, N., Sakr, S., Narangajavana, J., \& Chrestin, H. (2009). Involvement of HbP1P2;1 dan HbT1P1;1 aquaporins in ethylene stimulation of latec yield, through regulation of water exchanges between inner liber and latex cells in Hevea brasiliensis. Plant Physiology. 151(2), 843-856. doi: 10.1104/pp. 109.140228
Webster, C.C., \& Paardekooper, E.C. (1989). Rubber: The botany of the rubber tree. Essex, UK: Longman Scientific and Technical.

riasi massa selulosa. Jurnal Kimia Khatulistiwa, 4(3), 65-72. 